\title{
High nature value farmlands: challenges in identification and interpretation using Cyprus as a case study
}

\author{
Maria Zomeni', Angeliki F. Martinou², Menelaos C. Stavrinides², \\ Ioannis N. Vogiatzakis' \\ I School of Pure and Applied Sciences, Open University of Cyprus, Cyprus 2 Department of Agricultural Scien- \\ ces, Cyprus University of Technology, Cyprus \\ Corresponding author: I.N. Vogiatzakis (ioannis.vogiatzakis@ouc.ac.cy)
}

Academic editor:Joseph Tzanopoulos | Received 17 July 2018 | Accepted 24 October 2018 | Published 21 December 2018

http://zoobank.org/1F989F72-3EB8-432C-8455-35CF879F0A3C

Citation: Zomeni M, Martinou AF, Stavrinides MC, Vogiatzakis IN (2018) High Nature Value farmlands: challenges in identification and interpretation using Cyprus as a case study. Nature Conservation 31: 53-70. https://doi.org/10.3897/ natureconservation.31.28397

\begin{abstract}
High Nature Value Farmland systems (HNVf) in Europe are recognised for their importance for biodiversity conservation and their extent is one of the impact indicators in the CAP monitoring and evaluation framework for the 2014-2020 cycle. Due to differences in farming typologies and data availability between nations, a common methodology for identifying HNVf does not exist, nor is considered appropriate. In the current study we use the Mediterranean island of Cyprus as a case study to highlight EU-wide issues for the identification and mapping of HNVf. We brought together under a common spatial framework datasets on farming typology, agro-chemical inputs, water use intensity and biodiversity data collected from public authorities and nature/biodiversity conservation organisations. Using an expert driven approach informed by a range of stakeholders, we identified and mapped potential HNVf areas employing a $1 \mathrm{~km}^{2}$ mapping grid as the reporting spatial framework under two storylines for defining farmland area within every grid cell: a liberal with $10 \%$ threshold and a conservative with $25 \%$ threshold. Areas containing potentially HNVf may extend from $22.5-34.5 \%$ of the island, depending on the storyline employed. HNVf Type I is the more restricted type for both storylines, while Type II is the most extensive. The highest overlap was between Type II and Type III for the liberal storyline and between Type I and II for the conservative storyline. HNVfs cover an area between 30 to $57 \%$ of the Natura2000 network on the island depending on the storyline. With the liberal storyline for farmland definition, the spatial extent of HNVfs together with the existing Natura2000 sites cover $90 \%$ of the study area, while with the conservative storyline this figure drops to ca.75\%. The results confirm the role of HNVfs within and around Natura2000 sites in Cyprus and their potential for providing connection and site buffering opportunities, particularly in the lowlands, while they can provide information about policy-making for agri-environmental payments targeting.
\end{abstract}

Copyright Maria Zomeni et al. This is an open access article distributed under the terms of the Creative Commons Attribution License (CC BY 4.0), which permits unrestricted use, distribution, and reproduction in any medium, provided the original author and source are credited. 


\section{Keywords}

biodiversity, conservation, Mediterranean island, Natura2000, policy-making

\section{Introduction}

Many environmental threats, including climate change, biodiversity loss and degradation of land and freshwater are attributed to unsustainable agricultural practices (Foley et al. 2011). Agricultural intensification worldwide has had tremendous impacts on habitats, biodiversity and ecosystem functions and services (Zhang et al. 2007, Power 2010, Foley et al. 2011). The success of key environmental policy and legislation related to climate change targets (e.g. Roadmap to 2050) and meeting the 2020 biodiversity targets are heavily dependent on agricultural activities. In fact, Target 3 of the EU 2020 Biodiversity Strategy states explicitly that, by 2020, measures must be taken to "bring about a measurable improvement in the conservation status of species and habitats that depend on or are affected by agriculture and in the provision of ecosystem services as compared to the EU2010 Baseline" (http://www.alter-net.info/).

Agroecosystems are often considered incompatible with conservation and protection. However, in Europe the growing recognition that biodiversity conservation depends on the persistence of low-intensity farming systems catalysed the formation of the concept of High Nature Value farmland (HNVf) (Beaufoy and Jones 2012). HNVfs are parcels of farmland that are expected to support high levels of biodiversity or species and habitats of conservation concern because of certain features. HNVfs are classified into three categories, depending on the presence of semi-natural vegetation in the farmland, the diversity of low input farmland and the presence of species of conservation concern (Table 1) (Paracchini et al. 2008; Beaufoy and Jones 2012).

HNVfs are present all over Europe and include semi-natural pastures and hay meadows in Western Europe, Ireland and the UK and traditional cropping and orchard systems where livestock activities can also be present, such as olive groves, vineyards and cork oaks in the Mediterranean (Oppermann et al. 2012; Keenleyside et al. 2014). The largest extent of HNV farmland is found in Southern Europe with Spain having the highest percentage of HNVfs with respect to its utilised agricultural area (Keenleyside et al. 2014). HNVfs offer a great range of ecosystem services in addition to food provision, such as maintenance of crop genetic diversity, biocontrol services, erosion control, pollination and recreation services, while at the same time, they support rural livelihoods in remote areas (Keenleyside et al. 2014). HNVf landscapes are important for their ecological, cultural and socio-economic role. Some systems, such as the dehesas or montados in Spain and Portugal or the vineyards producing the sweet wine Commandaria on the south-western foothills of Cyprus, are historic landscapes. HNVfs have the potential to offer economic benefits and sustain rural populations as well as create benefits for the agrotourism industry and the wider public (O'Rourke et al. 2016).

The percentage of HNVf relative to the total utilised agricultural area (UAA) is acknowledged as an important indicator for monitoring landscape changes at spatial and 
temporal scales, as it is sensitive to anthropogenic impacts and it can be easily communicated in a policy-relevant context. The identification of HNVf in EU member states (MS) and monitoring its extent and condition is a policy instrument for agriculture and nature conservation purposes. HNVf is one of the 32 agri-environmental indicators developed by Eurostat to monitor the effects of agriculture on the environment and one of the impact indicators in the Common Monitoring and Evaluation Framework of CAP (http://epp.eurostat.ec.europa.eu/). At the same time, it is also a series of practical measures for biodiversity conservation (i.e. as habitats) and for providing valuable connections in the landscape for species movement (Doxa et al. 2012; Sutherland et al. 2010). For instance, vineyards and carob groves in Cyprus, provide feeding and breeding grounds to a diverse range of organisms, including many species listed in the Birds and Habitats Directives, such as the endemic birds, Cyprus warbler (Sylvia melanothorax) and Cyprus wheateater (Oenanthe cypriaca), as well as raptors, including the kestrel (Falco tinunculus) and the long-legged buzzard (Buteo rufinus). Along with bird species, many key insect species such as the critically endangered beetle Propomacrus cypriacus and a diverse range of pollinators, reside in agricultural fields and their margins (Sparrow and John 2016).

Regrettably, HNVf systems are currently threatened by two major opposing forces, intensification on the one hand (e.g. high inputs of pesticides or overgrazing) and land abandonment on the other. On the Mediterranean island of Cyprus, both forces have been acting simultaneously on the landscape for the last 50 years. The Utilized Agricultural Area (UAA) has seen a dramatic decline (Cyprus Statistical Service 2012) with extensive cereal crops and vineyards experiencing the largest decline. Intensification and land abandonment stem from the farmers' need to increase their income which is usually a response to political and economic imperatives. Especially in marginal areas, a farmer's profit can be discouragingly low for managing the land in a traditional, sustainable manner. The current challenge is to identify and apply strategies which will maintain the ecological benefits and create further socioeconomic turnover for the stewards of the HNV farming land across Europe. An essential first step towards this goal is defining what constitutes an HNVf system, describing its particular features and mapping HNVf land for each EU MS.

The methodology proposed by Andersen et al. (2003), revised by Paracchini et al. (2006), provides a European HNVf map which is not sufficiently accurate for applications at national and regional levels. Therefore MS are advised to use this indicative method (Beaufoy and Cooper 2008) and apply at national level, by adapting it to their specific conditions and contexts (EEA 2016). To this end, there have been various attempts to HNVf mapping (Hazeu et al. 2014; Halada et al. 2011; Galdenzi et al. 2012). In the case of Types I and II, two complementary approaches have been employed. The first is based on the use of land cover maps, which is suited for the localisation of HNV farmland areas. The second is the farm system typology, which combines agronomic and economic data derived from farms (e.g. FADN). The methodology employed at various national attempts follows or relies principally on the one proposed at the European level by Paracchini et al. (2006). Most attempts at national level use coarse data and therefore only approximate the spatial location of HNVfs. In a paper by Lomba et al. (2014), the caveats associated with the identification, mapping 
and monitoring of HNVfs in Europe are discussed, many of which stem from the very definition and concepts associated with HNVfs. The various attempts so far demonstrate that the methodology proposed is 'confusing' and is interpreted in different ways when applied (Lomba et al. 2014; Lomba et al. 2015).

Agriculture in Cyprus is characterised by a mosaic pattern of small plots with a diversity of permanent and arable crops. Two thirds of the farms in Cyprus are less than 20 ha in size (FSS 2007) while extensive farmlands with olives, carobs and vineyards have resulted in a diversity of cultural landscapes (Vogiatzakis and Manolaki 2017). This in turn provides an invaluable habitat to a rich biodiversity and, in particular, avifauna found within and around Natura2000 sites (Hellicar 2012). Yet and despite their importance for natural and cultural heritage, to date the extent of these High Nature Value farmlands on the island has not been sufficiently mapped. Therefore the objectives of the paper are to a) characterise and map HNVfs in Cyprus, adapting where necessary existing methodologies and b) identify potential synergies of HNVfs and the current spatial configuration of Natura 2000 areas.

\section{Methodology}

\section{Study area}

Cyprus is the third-largest Mediterranean island and a biodiversity hot-spot with high levels of endemism (Tsintides et al. 2007). Agricultural fields cover ca. 50\% of the land surface of the island in which the Government of the Republic of Cyprus exercises full control (CYGCA). Mapping was confined to these areas (CYGCA) since there were no data available for the northern part of the island.-In the last 40 years, the Utilized Agricultural Area (UAA) of Cyprus has seen a dramatic decline, from approximately 180,000 ha in 1975 to 115,000 in 2012 (Cyprus Statistical Service 2012). The largest acreage decrease was observed for cereals and vines, two extensive crops, which could potentially meet the definition of HNVf. Cereal crops (mostly rain-fed barley) decreased from a maximum of 73,000 ha in 2003 to 38,000 ha in 2012 , while vineyards dropped from a maximum of 35,000 ha in 1975 to 7,000 ha in 2012. Carob groves, another extensive crop and an important feature of the island's landscapes, have also seen a dramatic reduction from 7,000 ha in 1985 (earliest available data) to 1,700 ha in 2012. Approximately $10 \%$ of the UAA of Cyprus is used for growing intensive crops, mainly vegetables, potatoes, citrus and other fruits.

\section{Datasets and mapping process}

Mapping of HNVfs usually relies on four sets of indicators (Lomba et al. 2014): landscape elements, extensive practices, crop diversity and indicator species. We followed a similar approach and employed high resolution data with experts' opinion and fine- 


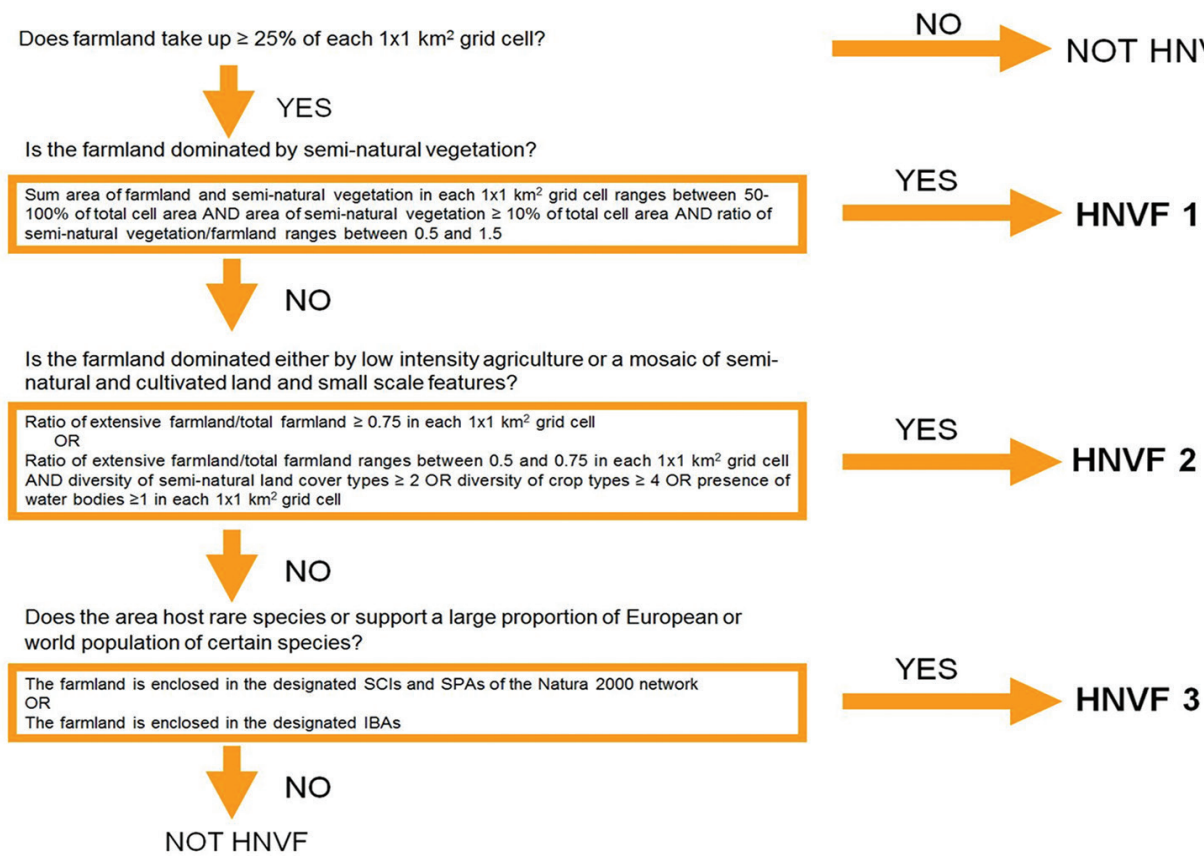

Figure I. Selection rules for mapping the three types of potentially HNVfs in Cyprus using the conservative storyline ( $25 \%$ threshold). The liberal storyline was applied with identical rules with the exception of the $10 \%$ threshold for $\%$ farmland within every $1 \mathrm{~km}^{2}$ grid cell.

tuning according to ground-truthing and local conditions. High resolution spatial data from the land parcel information system (LPIS) for 2013 (the latest available dataset), containing the delimited plots at national level, were combined with farm system data from the Cyprus Agricultural Payments Organization (CAPO). The CAPO dataset provides information on the type of farm and type of crops cultivated on each plot, including grasslands. Plots, including non-claimed farmland (no financial support requested), were excluded from the analysis, since such farmland was not eligible for payment under CAPO and there is no reporting on crop types or on whether they are active or abandoned. This information along with datasets on farming typology rules, agro-chemical inputs, water use intensity, Natura2000 sites, water bodies and Important Bird Areas (IBAs) were collated in a common spatial framework.

These data were complemented with CORINE Land Cover 2012 data (1:250,000) for the distribution of semi-natural vegetation. Seventeen CORINE level three types were used, namely the categories: 3.1.1, 3.1.2, 3.1.3, 3.2.1, 3.2.2, 3.2.3, 3.2.4, 3.3.1, 3.3.2, 3.3.3, 3.3.4, 4.1.1., 4.2.1, 4.2.2, 4.2.3, 5.1.2, 5.2.2. CORINE land cover data provided the best proxy information on the distribution pattern of semi-natural vegetation, since national data at similar or finer scales do not include all semi-natural categories and were produced with different schemes and for different purpose (e.g. the state forests map of the island). 
Table I. HNVf definitions and mapping: A comparison between JRC's approach (Paracchini et al. 2008) and this study.

\begin{tabular}{l|l|l}
\hline \multicolumn{1}{c|}{ Definitions } & JRC's approach & \multicolumn{1}{c}{ Approach employed herein } \\
\hline $\begin{array}{l}\text { Type I: Farmland with a high proportion of semi- } \\
\text { natural vegetation. }\end{array}$ & CLC cover types & $\begin{array}{l}\text { Field parcels for cropland; CLC for semi- } \\
\text { natural vegetation; Validation by stakeholders }\end{array}$ \\
\hline $\begin{array}{l}\text { Type II: Farmland with a mosaic of low intensity } \\
\text { agriculture and natural and structural elements, such } \\
\begin{array}{l}\text { as field margins, hedgerows, stone walls, patches of } \\
\text { woodland or scrub, small rivers etc. }\end{array}\end{array}$ & $\begin{array}{l}\text { CLC cover types; } \\
\text { Areas suggested by } \\
\text { stakeholders }\end{array}$ & $\begin{array}{l}\text { Field parcels for cropland; CLC for semi- } \\
\text { natural vegetation; Other mapped natural and } \\
\text { structural elements; Validation by stakeholders }\end{array}$ \\
\hline $\begin{array}{l}\text { Type III: Farmland supporting rare species or a high } \\
\text { proportion of European or World populations. }\end{array}$ & $\begin{array}{l}\text { CLC cover types; } \\
\text { IBAs }\end{array}$ & $\begin{array}{l}\text { Field parcels for cropland; CLC for semi- } \\
\text { natural vegetation; IBAs; Validation by } \\
\text { stakeholders }\end{array}$ \\
\hline
\end{tabular}

The spatial datasets were evaluated for the definition and mapping of HNVfs in Cyprus by combining the specific selection rules applied by JRC for Cyprus (Paracchini et al. 2008; Table 1) with principles of landscape ecology and field work (Fig. 1). A 1 $\mathrm{km}^{2}$ grid was overlaid on the study area and two scenarios were used for delineating potential areas with HNVf within each grid cell. In the first storyline, farmland occupies at least $10 \%$ of total grid cell area (liberal storyline), while in the second, this threshold is raised to $25 \%$ (conservative storyline). The first threshold was considered reasonable given the size of agricultural plots on the island (average of ca. $0.5 \mathrm{ha}$ ), the fact that not all farmland is registered with LPIS and also considering that many areas are subject to agricultural abandonment. The $25 \%$ threshold was considered adequate to characterise grid cells which are predominantly agricultural (i.e. pure agricultural matrix). In each grid cell, the total area of farmland and semi-natural vegetation were tabulated, as well as the share of extensive farmland, the presence of water bodies, the diversity of seminatural vegetation types (used for Type II) and crop diversity. The mapping rules were derived using a dichotomous key with a set of decisive questions which were in line with the definitions of HNVfs while their quantification (threshold setting) was a result of individual consultation with experts and subsequent fine-tuning (Fig.1).

The potential HNV farmland was delimited by combining the three HNV farmland-groups described in the European HNV indicator study of Andersen et al. (2003) (see Table 1; Fig. 2). The spatial relationship of HNVFs with the Natura2000 network on the island was assessed using a simple overlay process.

\section{Stakeholders' involvement}

Fourteen organisations were invited to the two workshops. These organisations represented the major stakeholders in land management in Cyprus, i.e. Government, NGOs, Universities and farmers' associations. Twelve organisations attended two workshops held in Nicosia with the numbers of participants (24 in total with complementary expertise) shown in brackets: Departments of Environment (3), Agriculture (2), Forests (3), Water Development (1), the Game and Wildlife Service (2), Birdlife Cyprus (2), Terra Cypria (2), 

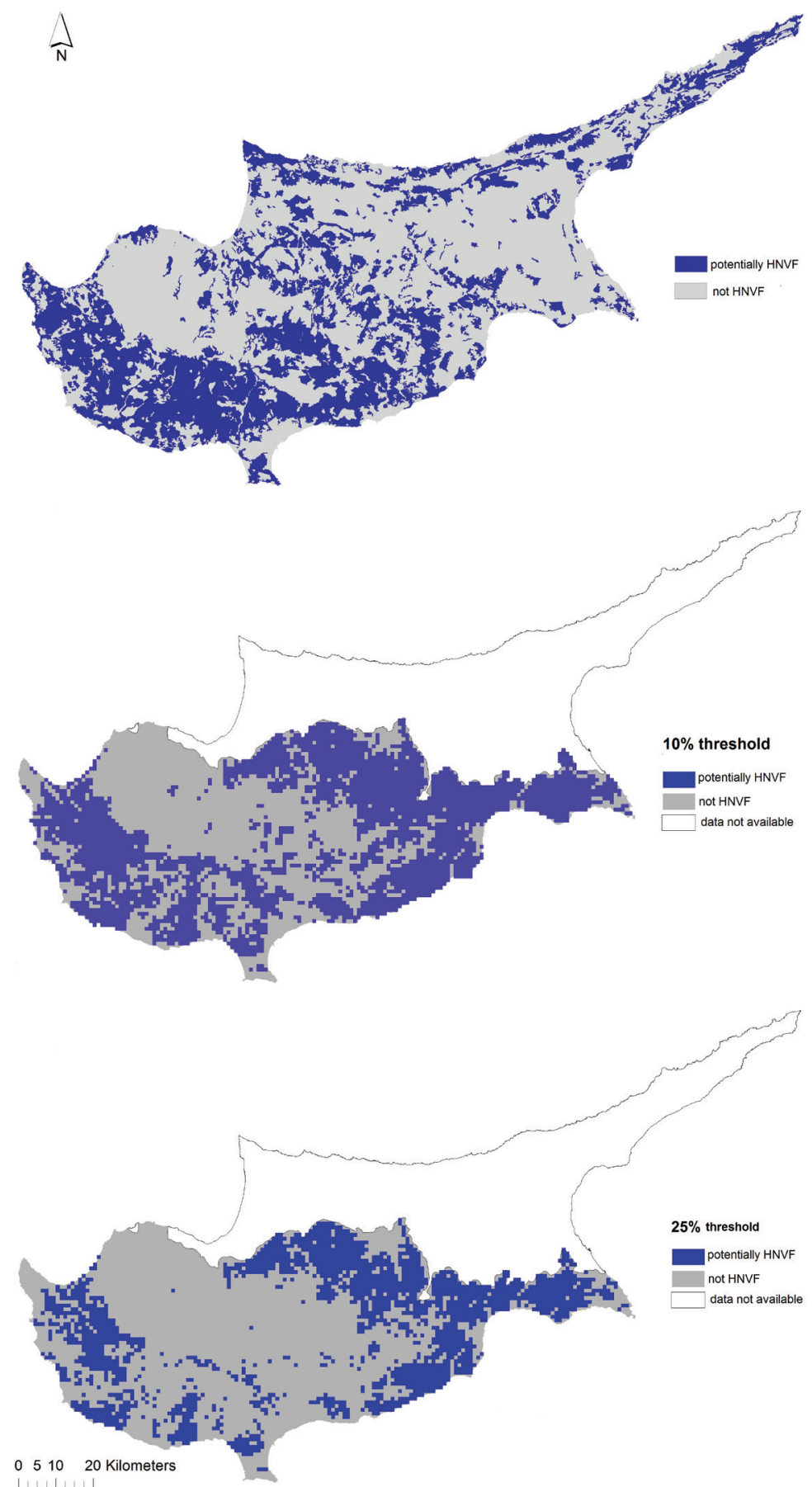

Figure 2. Extent of potentially HNVfs proposed by JRC (upper part) and potentially HNVfs according to the $10 \%$ threshold (middle part) and $25 \%$ thresholds in this study (lower part). 
Cyprus Federation of Environmental and Ecological Organisations (2), Management Authority for the Cyprus Rural Development Programme (1), Cyprus Agricultural Payments Organisation - CAPO (2), Cyprus University of Technology - Department of Agricultural Sciences (2), Open University of Cyprus - Terrestrial Ecosystem Management Lab (2).

The first workshop brought together, early in the process, stakeholders to discuss the definition of HNVf and the mapping methodology for the Cypriot context. These people, coming from different disciplines and expertise, were introduced for the first time to the proposed rule-based methodology and engaged in a productive dialogue to improve the mapping rules. The rules for mapping were explained and the use of various thresholds of farmland coverage within each grid cell was discussed. Important decisions were made, such as, for example, classifying extensive as opposed to intensive farming activity. More specifically, one hundred crop types were classified into low and high intensity types, based largely on irrigation and agrochemical use intensity. In addition it was agreed that the term farmland was to be used in accordance with other studies (e.g. Plieninger and Bieling 2013), to denote land suitable or used for all kinds of agricultural activities, including grazing where data was available. Stakeholders pointed out that all mapped areas sensitive to nitrate pollution because of intensive fertiliser use / livestock farms, as well as areas where intensive irrigation takes place (mainly the east part of the island), should be excluded from mapping. These areas were also corroborated during selected field visits.

The outcome of the mapping process was presented during the second workshop to the same stakeholders and supplementary amendments were suggested and taken into consideration. During the second workshop, stakeholders pointed out that HNVfTypes I and III were underestimated due to the under-representation of grazing lands in the mapping sources used (in both CORINE and CAPO). Conversely, HNVf II was considered overestimated for some areas since, according to stakeholders, the relative contribution of farmlands and natural/structural elements present in the estimation of 'mosaickness' should be somehow weighted with more emphasis placed on farmlands' presence. In addition, it was proposed that the most agriculturally intensive areas in the east of the island could be included in HNVf Type III only where there is confirmed presence of species of European importance (Type III). Stakeholders also commented that known occurrences of HNVfs in mountainous areas were omitted (i.e. areas with extensive presence of traditional stonewalls), particularly under the conservative storyline. The map was updated to reflect the changes proposed by the experts (see Results and Figure 4).

\section{Results}

\section{Identification and extent of $\mathrm{HNVfs}$}

The areal extent of the two HNVf storylines (25\% and 10\%) is given in Table 2. Areas containing potentially HNVf may extend from $22.5-34.5 \%$ of the island's surface, depending on the threshold employed. HNVf Type II dominates in both scenarios. HNVf Type I is the more restricted type for the 10\% threshold (Fig. 3a), while for 

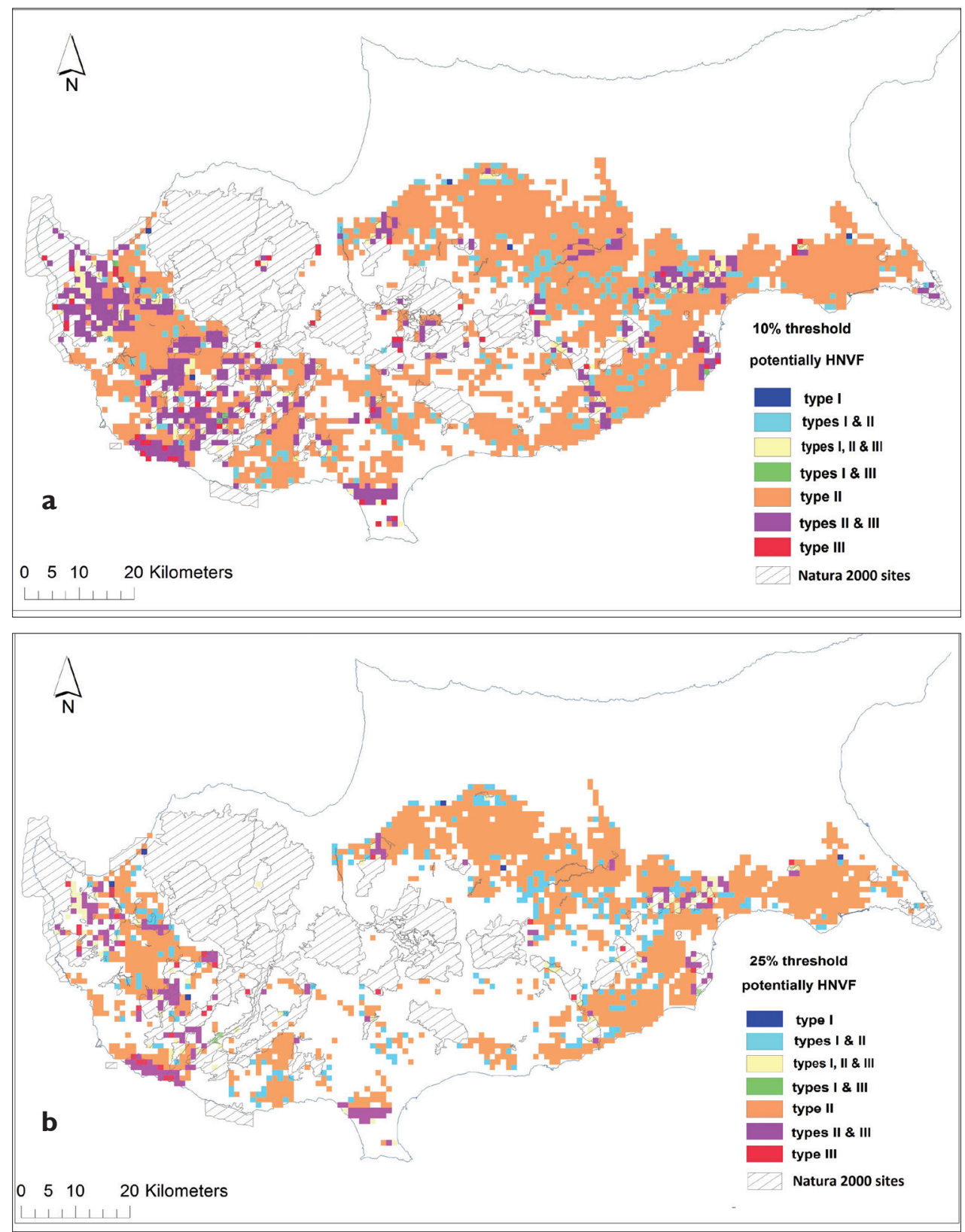

Figure 3. Potentially HNVf types according to a the $10 \%$ threshold and $\mathbf{b}$ the $25 \%$ threshold, in relation with existing Natura2000 sites.

the $25 \%$ threshold HNVf Type III becomes the most limited type (Fig. 3b). Type II is the most extensive category while Type III is the more restricted in distribution. With a $10 \%$ threshold, $3 / 4$ of the study area is under one or more HNVf categories. There were also cases where cells could be assigned to more than one HNVf category (Table 
Table 2. Extent of the HNVf types in the study area (CYGCA), showing also the extent of overlap between types.

\begin{tabular}{lcccccc}
\hline $\begin{array}{l}\text { Liberal storyline 10\% } \\
\text { threshold }\end{array}$ & Type I & Type II & Type III & Type I \& II \& III & Total & \% of island's surface \\
\hline $\begin{array}{l}\text { Type I } \\
\text { Type II }\end{array}$ & 5 & 233 & 4 & 100 & 342 & 3.7 \\
Type III & 233 & 2312 & 485 & 100 & 3130 & 33.8 \\
& 4 & 485 & 50 & 100 & 639 & 6.9 \\
& & & & & & $34.5^{*}$ \\
\hline $\begin{array}{l}\text { Conservative storyline } \\
\text { 25\% threshold }\end{array}$ & Type I & Type II & Type III & Type I \& II \& III & Total & \% of island's surface \\
\hline Type I & 6 & 239 & 3 & 75 & 323 & 3.5 \\
$\begin{array}{l}\text { Type II } \\
\text { Type III }\end{array}$ & 239 & 1553 & 171 & 75 & 2038 & 22 \\
& 3 & 171 & 30 & 75 & 279 & 3 \\
\hline
\end{tabular}

*due to HNVf types semantic and therefore mapping representation, overlap

Table 3. HNVf types within the Natura2000 network.

\begin{tabular}{cccccccccc}
\hline HNVf & Type I & $\begin{array}{c}\text { Type I } \\
\text { and II }\end{array}$ & $\begin{array}{c}\text { Type I, II } \\
\text { and III }\end{array}$ & $\begin{array}{c}\text { Type I } \\
\text { and III }\end{array}$ & Type II & $\begin{array}{c}\text { Type II } \\
\text { and III }\end{array}$ & Type III & Total & $\begin{array}{c}\text { \% of the } \\
\text { N2K sites* }\end{array}$ \\
\hline Area $\left(\mathbf{k m}^{2}\right) \mathbf{1 0} \%$ & 0 & 3 & 47 & 3 & 83 & 256 & 39 & 431 & 57 \\
Area $\left(\mathbf{k m}^{2}\right) \mathbf{2 5} \%$ & 2 & 21 & 43 & 3 & 76 & 35 & 48 & 228 & 30 \\
\hline
\end{tabular}

*the extent of terrestrial part of the Natura2000 (N2K) sites on Cyprus (CYGCA) is $752.6 \mathrm{~km}^{2}$

2). The highest overlap was between Type II and Type III for the liberal storyline and between Type I and II for the conservative storyline (Table 2).

During the second workshop, there was a general agreement amongst stakeholders that the map based on the $10 \%$ threshold better represented HNVf on the island. However, workshop participants pointed out that some amendments were required to improve HNVf representation; for instance, the exclusion of intensive agricultural lands on the east of the island, unless there was confirmed presence of species of European importance (see Materials and Methods). The incorporation of stakeholders' comments in the mapping process resulted in changes as explicitly shown in Figure 4. This resulted in the final map based on the $10 \%$ threshold (Fig. 4) which was adopted by the Ministry for reporting to the EU.

\section{Spatial relation of HNVfs to Natura2000 network}

When we applied a $10 \%$ threshold for farmland definition within every grid cell, there is a total of $431 \mathrm{~km}^{2}$ of HNVfs in Cyprus already situated in the Natura2000 network, almost half belonging to cells characterised as both Type II $\&$ III. When we applied a $25 \%$ threshold, this figure is reduced to 228 , although again half belong to cells characterised as both Type II \& III. However, in this storyline, there are 43 cells within Natura2000 which are characterised as Type I, II and III (Table 3). 


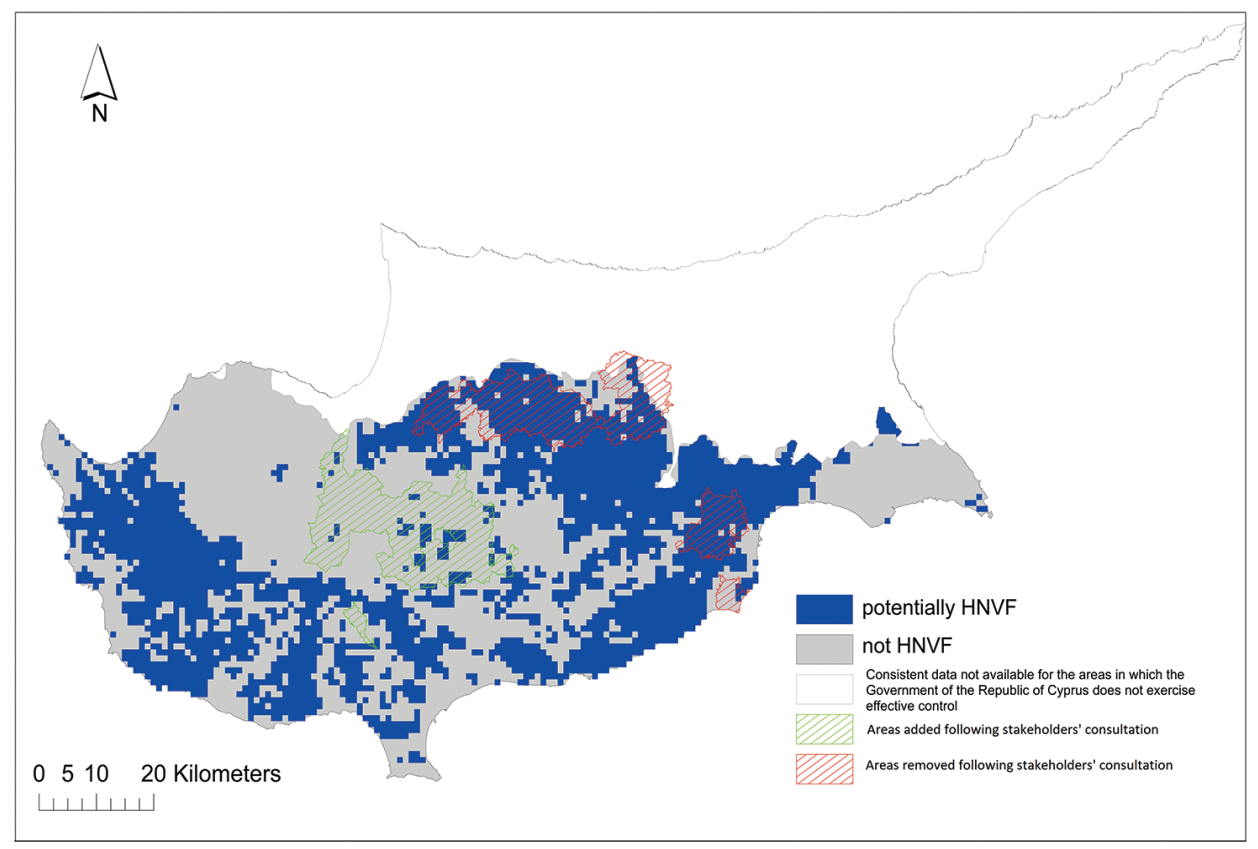

Figure 4. Final HNVf map (10\% threshold) following stakeholders' consultation.

In the case of the liberal storyline (10\% threshold), the spatial extent of HNVfs, together with the existing Natura2000 sites, cover $90 \%$ of the study area (Figure 3) while, with the conservative storyline (25\% threshold), this figure drops to ca. $75 \%$ of the study area (Figure 3). The 10\% threshold results in substantial buffering around lowland Natura2000 sites in the central and east part of the island as, for example, Potamos Panagias Stazousas (CY6000007) - Kosiis Pallourokampou (CY6000009) - Alykes Larnakas (CY6000002) sites and more physical connections between Natura2000 in the landscape compared to the $25 \%$ threshold (Figure 4). The only exception is the southeastern corner of the island where there is no connection or buffer between Cavo Gkreko (CY3000005), Limni Paralimniou (CY000008) and Fragma Achnas (CY000007). In the case of $25 \%$ threshold, there is no buffering effect around most of the Natura2000 sites of the central and east part of the island, while there is a lack of physical connection between most of the lowland Natura2000 areas, irrespective of the geographical location/district.

\section{Discussion}

The identification and mapping of High Nature Value farmlands is of utmost importance in preventing biodiversity loss but also in aiding with their preservation against intensification or abandonment (Andersen et al. 2003; EEA 2004; Paracchini et al. 2008). Although there is no doubt that the standard established procedures (Paracchini et al. 2006) provide guidance, it was obvious from the outset of this study that 
refinement is necessary at the national level, if HNVf delineation is to be of practical use for policy formulation and planning. On one hand, methodologies should not be prescriptive due to ecological historical and cultural differences across farming landscapes in Europe. On the other hand, the existing approaches are subject to a variety of interpretations and thus are problematic, while the dependency on local conditions and spatial datasets clearly influences the result (see also review by Lomba et al. 2014).

A previous study by JRC classified ca. $37 \%$ of the whole island as possible HNVf (Paracchini et al. 2008). However, the present study suggests that this percentage might be even higher given that mapping of the southern part of the island, which is under the effective control of the Republic of Cyprus government, resulted in $22.5 \%$ and $34.53 \%$ of the island's surface being potential HNVfs (depending on the storyline employed). This is the first study for Cyprus which takes into account expert derived information following a wide consultation and detailed GIS data on crop distribution, in addition to biodiversity datasets (IBAs) in order to classify HNVfs. Despite the availability of crop datasets in very high resolution, they had to be aggregated using a consistent spatial framework. The $1 \mathrm{~km}^{2}$ grid chosen was small enough to accommodate the average size of farms in Cyprus and large enough to contain additional elements to account and measure heterogeneity in the wider landscapes (mosaickness). The approach is consistent with other HNVf studies (e.g. Kikas et al. 2017; Paracchini et al. 2008). Even so, there are some notable differences in the distribution of HNVfs between our approach and that of JRC's (Fig. 2), particularly in the southeast and central part of the island, with a better match obtained when using the $10 \%$ threshold. As pointed out by the stakeholders involved in the process, the conservative storyline (25\%) performs better in the lowlands where agriculture dominates but not in the uplands where agricultural plots are, on average, smaller in size and have fragmented distribution.

Scale is an important issue and the proposed HNVf methodology (Paracchini et al. 2008) should be revised to include different levels of data and different scales of analysis. At the European level, we need a nested hierarchical-based methodology (similar to CORINE), both in terms of spatial and thematic resolution, which countries can adapt according to the level and dataset availability. Traversing from coarse thematic resolution as derived from EU level CORINE, to fine thematic resolution as provided by CAPO in the case of Cyprus, proved problematic since there is no direct relationship between CORINE and CAPO classes and mapping schemes. This clearly demonstrated that the mapping result is directly related to the datasets employed, although conceptually the definition of HNVfs remains constant.

The need for identifying HNVf at the national level is as pressing as the need for clear definitions, e.g. in areas where semi-natural habitats form mosaics with more intensive agriculture. Perhaps from the three HNVf types, Type I is clearer and more consistently mapped across case studies (countries) while is also more easily identified when widespread, especially in marginal regions of Europe (Lomba et al. 2015; Beaufoy and Jones 2012). Type III definition is very clear, as it refers to farmland able to support populations of species of conservation concern, independently of farming 
intensity (Beaufoy and Jones 2012). Species data availability, particularly useful for characterising HNVf Type III, is greater in the north than in the south of Europe.

Determining Type II systems can be quite subjective as each case-scenario requires some value judgement as to what is the right proportion of semi-natural habitat needed to sustain wildlife populations. Tscharntke et al. (2005) refer to landscapes with more than 20\% semi-natural habitats as complex landscapes while those with 2-20\% seminatural land are considered as structurally simple. The landscapes with less than $2 \%$ of semi-natural land are referred to as cleared landscapes with limited conservation value. Le Roux et al. (2008) consider $20 \%$ to be the minimum threshold for maintaining significant biodiversity on farmland (Beaufoy and Jones 2012). Different approaches have also been employed, such as the one by Halada et al. (2011) who propose the inclusion of Annex I habitat types depending on agricultural management, while in Italy, Galdenzi et al. (2012) based their work on current and potential vegetation cover data obtainable from different integrated vegetation maps. The geographical context is evidently important in HNVf definition and mapping with fine grained mosaics characterising southern Europe landscapes compared to their counterparts in the north (Pinto Correia et al. 2018).

The area of agricultural land, classified as HNVf, has been proposed as a key indicator to monitor the impact of CAP of the environment in the 2007-2013 funding cycle and is a prominent metric for the next cycle of RDP (2014-2020). Within Axis 2 of the CAP, the agri-environmental measures are amongst the most important instruments for the support of traditional or HNVf farming (Pe'er et al. 2014). In Cyprus, $43 \%$ of the total public 2007-2013 RDP expenditure of 282 million Euros was paid for agri-environmental commitments. However, most of the funding allocated to Axis 2 did not target biodiversity conservation directly and included measures on financial support for certification schemes, such as GlobalCAP, in intensive citrus crops and potatoes. A measure specifically targeting HNVf conservation was included in the 20142020 RDP after the mid-term evaluation of 2017, just after the adoption of the current HNVf map. This measure targets cereals and tree crops: olive, carob and hazelnut.

Pressure on EU habitats and ecosystems is still prevalent. Only 17\% of EU habitats and $11 \%$ of ecosystems are considered to be in a favourable state, nutrient surpluses persist in some water bodies (despite progress in others) and 45\% of EU soils suffer from problems of quality (Pe'er et al. 2014). These challenges need to be addressed and the positive environmental contribution of farming and forestry should be strengthened. The Lawton Review (Lawton et al. 2010) advocates management of the countryside at landscape level to ease pressures on Protected Areas. HNVf areas have received increasing attention at the European level due to their importance for biodiversity conservation and their potential for establishing future connections amongst different protected areas (Strohbach et al. 2015). Even under the conservative storyline i.e. 25\% threshold, in Cyprus more than 22.5\% of the island's territory falls into one of the three HNVfs' categories, bearing in mind that this study did not map the whole island. In addition, in many areas, there is an overlap in HNVf types (Table 2) pointing to the difficulty in characterising these areas in Cyprus under the existing HNVf definitions. 
This highlights the importance for managing HNVfs for promoting nature conservation and safeguarding species and processes at regional and national level (Morelli 2018), in a complementary way to the existing Natura2000 network. Examples are already emerging in Europe where this is already taking place (Klimek et al. 2014; Sigura et al. 2010. There is a two-fold importance in this, since landscape level management has also been advocated as part of a wider adaptation policy to tackle climate change effects on biodiversity (Vos et al. 2008). These areas have the potential to facilitate spatial planning for nature conservation since establishing new protected areas will be more likely met with resistance due to competition with other land-uses. This is even more important in an island context where land availability is limited. Improving the conservation value of agricultural lands has been proposed as a complementary strategy (Troupin and Carmel 2014). However Kleijn et al. (2011) contest this and suggest that it is unknown how the extensive European agri-environmental budget for conservation on farmland contributes to the policy objectives to halt biodiversity decline.

Currently, the terrestrial part of the designated Natura2000 sites on Cyprus (CYGCA) cover $752.6 \mathrm{~km}^{2}$ and, although the percentage of habitats in a favourable state within the network is reported to be the highest in the EU (EEA 2016), a recent study on the effectiveness of the protected areas on the island suggests that this is far from adequate for conserving biodiversity (Christodoulou et al. 2018). These gaps more often than not relate to the site specific conservation measures implemented in Natura2000 sites without so much consideration of landscape level processes such as habitat connectivity or fragmentation (Opdam et al. 2006). Since establishing new protected areas to enhance the networks connectivity is unlikely, protecting and maintaining these HNVf areas can facilitate spatial planning and help address these gaps in nature conservation by designing appropriate ecological networks. As demonstrated by the results herein, HNVfs provide links amongst all Natura2000 sites which may improve the connectivity of the network and therefore its effectiveness for biodiversity conservation, although quantifying the degree of connectivity was beyond the scope of this study.

In particular, HNVfs can provide buffering from externalities to the lowland Natura2000 sites which are under more pressure compared to their upland counterparts, due to their proximity to intensive agricultural and tourist activities. This is of utmost important for sites Potamos Panagias Stazousas (CY6000007) - Kosiis Pallourokampou (CY6000009) which host species such as Sylvia melanothorax, Oenanthe cypriaca, as well as Falco tinunculus and the long-legged buzzard (Buteo rufinus). The next step would be to identify and design ecological networks amongst Natura2000 sites with their constituent elements (buffers, corridors, stepping stones). A target site could be the Alykes Larnakas (CY6000002) where, physically, the site is split into two due to the construction of the international airport. Starting with the HNVfs' mapping, the challenge in Cyprus is to highlight synergies between nature conservation and agricultural production and to raise awareness about their importance and the financial opportunities they provide.

The high percentage of HNVfs in Cyprus may be good news for conservationists but disquieting for farmers unless they are somehow convinced that HNVfs have real 
benefit for them. Farmers, but also other stakeholder groups, as demonstrated during the workshops held for this case study, are apprehensive when it comes to lines on the map. When the discourse is about conservation elements, the assumption is that delineation will lead to designation and strict protection where restrictions to land management will apply. Already the erroneous perception on the concept of Natura2000 proves that management in the private lands within the Natura2000 network is problematic in Cyprus but also elsewhere in Europe (Hiedanpää 2002). A review by Plieninger and Bieling (2013) highlighted the vulnerability of HNVfs to socioeconomic changes and the need for a new dynamic and adaptive strategy for increasing their long term resilience. Such a strategy though can be effective only if supported by reliable HNVf mapping.

\section{Aknowledgements}

We would like to thank the Department of Environment (MANRE) for support and in particular E. Stylianopoulou and M. Xenophontos. In addition, we would like to thank all stakeholders who participated in the two workshops. This study was partly funded by LIFE13 BIO/CY/00114. AgroLIFE: To promote and enable the conservation of High Nature Value Farmlands in Cyprus. EU LIFE + Biodiversity Project.

\section{References}

Andersen E, Baldock D, Bennet H, Beaufoy G, Bignal E, Brower F, Elbersen B, Eiden G, Godeschalk F, Jones G, McCracken DI, Nieuwenhuizen W, van Eupen M, Hennekes S, Zervas $G$ (2003) Developing a high nature value farming area indicator. Consultancy report to the EEA. European Environment Agency, Copenhagen, 75 pp.

Beaufoy G, Jones G (2012) HNV farming in England and Wales - findings from three local projects. http://www.efncp.org/download/HNV_Farming_brochure_final.pdf

Beaufoy G, Cooper T (2008) Guidance document to the member states on the application of the high nature value impact indicator. Internetseite European evaluation network for rural development, Brüssel.

Christodoulou CS, Griffiths GH, Vogiatzakis IN (2018) Using threatened plant species to identify conservation gaps and opportunities on the island of Cyprus. Biodiversity and Conservation 27(11): 2837-2858. https://doi.org/10.1007/s10531-018-1572-4

Cyprus Statistical Service (2012) Agricultural Statistics 2009-2010. http://www.mof. gov.cy/mof/cystat/statistics.nsf/agriculture_51 main_gr/agriculture_51 main_ gr?OpenForm\&sub=5\&sel=1

Doxa A, Paracchini ML, Pointereau P, Devictor V, Jiguet F (2012) Preventing biotic homogenization of farmland bird communities: The role of High Nature Value farmland. Agriculture, Ecosystems \& Environment 148: 83-88. https://doi.org/10.1016/j.agee.2011.11.020

EEA (2004) High Nature Value Farmland - Characteristics, Trends and Policy Challenges. EEA, European Environment Agency, Copenhagen, 32 pp. 
EEA (2016) Proportion of species assessments in each conservation status class per Member State. https://www.eea.europa.eu/data-and-maps/daviz/proportion-of-species-assessmentsin\#tab-chart_1

Foley JA, Ramankutty N, Brauman KA, Cassidy ES, Gerber JS, Johnston M, Mueller ND, O'Connell C, Ray DK, West PC, Balzer C, Bennett EM, Carpenter SR, Hill J, Monfreda C, Polasky S, Rockstrom J, Sheehan J, Siebert S, Tilman D, Zaks DPM (2011) Solutions for a cultivated planet. Nature 478(7369): 337-342. https://doi.org/10.1038/nature10452

FSS (2007) Farm Structure Survey in Cyprus - 2007 - Issue number 82/2009. Eurostat.

Galdenzi D, Pesaresi S, Casavecchia S, Zivkovic L, Biondi E (2012) The phytosociological and syndynamical mapping for the identification of High Nature Value Farmland. Plant Sociology 49: 59-69.

Halada L, Evans D, Romão C, Petersen JE (2011) Which habitats of European importance depend on agricultural practices? Biodiversity and Conservation 20(11): 2365-2378. https:// doi.org/10.1007/s10531-011-9989-z

Hazeu G, Milenov P, Pedroli B, Samoungi V, Van Eupen M, Vassilev V (2014) High Nature Value farmland identification from satellite imagery, a comparison of two methodological approaches. International Journal of Applied Earth Observation and Geoinformation 30: 98-112. https://doi.org/10.1016/j.jag.2014.01.018

Hellicar M (2012) Cyprus. In: Oppermann R, Beaufoy G, Jones G (Eds) High Nature Value Farming in Europe. Verlag Regionalkultur, Ubstadt-Weiher, 544 pp.

Hiedanpää J (2002) European-wide conservation versus local well-being: The reception of the Natura 2000 Reserve Network in Karvia, SW-Finland. Landscape and Urban Planning 61(2-4): 113-123. https://doi.org/10.1016/S0169-2046(02)00106-8

Keenleyside C, Beaufoy G, Tucker G, Jones G (2014) High Nature Value farming throughout EU-27 and its financial support under the CAP. Report Prepared for DG Environment, Contract No ENV B.1/ETU/2012/0035, Institute for European Environmental Policy, London.

Kikas T, Bunce RG, Kull A, Sepp K (2017) New high nature value map of Estonian agricultural land: Application of an expert system to integrate biodiversity, landscape and land use management indicators. Ecological Indicators. https://doi.org/10.1016/j.ecolind.2017.02.008

Kleijn D, Rundlöf M, Scheper J, Smith HG, Tscharntke T (2011) Does conservation on farmland contribute to halting the biodiversity decline? Trends in Ecology \& Evolution 26(9): 474-481. https://doi.org/10.1016/j.tree.2011.05.009 PubMed

Klimek S, Lohss G, Gabriel D (2014) Modelling the spatial distribution of species-rich farmland to identify priority areas for conservation actions. Biological Conservation 174: 6574. https://doi.org/10.1016/j.biocon.2014.03.019

Lawton JH, Brotherton PNM, Brown VK, Elphick C, Fitter AH, Forshaw J, Haddow RW, Hilborne S, Leafe RN, Mace GM, Southgate MP, Sutherland WA, Tew TE, Varley J, Wynne GR (2010) Making Space for Nature: a review of England's wildlife sites and ecological network. Report to Defra.

Le Roux X, Barbault R, Baudry J, Burel F, Doussan I, Garnier E, Herzog F, Lavorel S, Lifran R, Roger-Estrade J, Sarthou JP, Trommetter M (Eds) (2008). Agriculture et biodiversité: valoriser les synergies. Expertise scientifique collective, synthèse du rapport, INRA (France). 
Lomba A, Alves P, Jongman RH, McCracken DI (2015) Reconciling nature conservation and traditional farming practices: A spatially explicit framework to assess the extent of High Nature Value farmlands in the European countryside. Ecology and Evolution 5(5): 10311044. https://doi.org/10.1002/ece3.1415 PubMed

Lomba A, Guerra C, Alonso J, Honrado JP, Jongman R, McCracken D (2014) Mapping and monitoring High Nature Value farmlands: Challenges in European landscapes. Journal of Environmental Management 143: 140-150. https://doi.org/10.1016/j.jenvman.2014.04.029

Morelli F (2018) High nature value farmland increases taxonomic diversity, functional richness and evolutionary uniqueness of bird communities. Ecological Indicators 90: 540-546. https://doi.org/10.1016/j.ecolind.2018.03.035

O’Rourke E, Charbonneau M, Poinsot Y (2016) High nature value mountain farming systems in Europe: Case studies from the Atlantic Pyrenees, France and the Kerry Uplands, Ireland. Journal of Rural Studies 46: 47-59. https://doi.org/10.1016/j.jrurstud.2016.05.010

Opdam P, Steingröver E, Van Rooij S (2006) Ecological networks: A spatial concept for multiactor planning of sustainable landscapes. Landscape and Urban Planning 75(3-4): 322332. https://doi.org/10.1016/j.landurbplan.2005.02.015

Oppermann R, Beaufoy G, Jones G (Eds.) (2012) High Nature Value Farming in Europe - 35 European countries - experiences and perspectives, $544 \mathrm{pp}$.

Paracchini ML, Petersen JE, Hoogeveen Y, Bamps C, Burfield I, van Swaay C (2008) High nature value farmland in Europe. An estimate of the distribution patterns on the basis of land cover and biodiversity data. EUR, 23480.

Paracchini ML, Terres JM, Petersen JE, Hoogeveen Y (2006) Background document on the methodology for mapping High Nature Value farmland in EU27. European Commission Directorate General Joint Research Centre and the European Environment Agency, 32 pp. Pe’er G, Dicks GL, Visconti V, Arlettaz P, Báldi R, Benton A, Collins TG, Dieterich S, Gregory M, Hartig RD, Henle F, Hobson K, Kleijn PR, Neumann D, Robijns RK, Schmidt T, Shwartz J, Sutherland A, Turbé WJ, Wulf A, Scott F (2014) EU agricultural reform fails on biodiversity. Science 344(6188): 1090-1092. https://doi.org/10.1126/science.1253425

Pinto-Correia T, Guiomar N, Ferraz-de-Oliveira MI, Sales-Baptista E, Rabaça J, Godinho C, Ribeiro N, Sousa PS, Santos P, Santos-Silva C, Simôes MP (2018) Progress in Identifying High Nature Value Montados: Impacts of Grazing on Hardwood Rangeland Biodiversity. Rangeland Ecology and Management 71(5): 612-625. https://doi.org/10.1016/j. rama.2018.01.004

Plieninger T, Bieling C (2013) Resilience-based perspectives to guiding high-nature-value farmland through socioeconomic change. Ecology and Society 18(4): art20. https://doi. org/10.5751/ES-05877-180420

Power AG (2010) Ecosystem services and agriculture: tradeoffs and synergies Phil. Trans. R. Soc. B 365: 2959-2971. https://doi.org/10.1098/rstb.2010.0143

Sigura M, Peccol E, Piani L (2010) High Nature Value Farmland (HNVf) and Ecological Networks: Their Role in the Sustainability of Trans-Border Regions. disP-The Planning Review 46: 60-68. https://doi.org/10.1080/02513625.2010.10557112

Sparrow D, John E (Eds) (2016) An introduction to the wildlife of Cyprus. Terra Cypria, 897 pp. 
Strohbach MW, Kohler ML, Dauber J, Klimek S (2015) High nature value farming: From indication to conservation. Ecological Indicators 57: 557-563. https://doi.org/10.1016/j. ecolind.2015.05.021

Sutherland WJ, Albon SD, Allison H, Armstrong-Brown S, Bailey MJ, Brereton T, Boyd IL, Carey P, Edwards J, Gill M, Hill D, Hodge I, Hunt AJ, Le Quesne WJF, Macdonald DW, Mee LD, Mitchell R, Norman T, Owen RP, Parker D, Prior SV, Pullin AS, Rands MRW, Redpath S, Spencer J, Spray CJ, Thomas CD, Tucker GM, Watkinson AR, Clements A (2010) The identification of priority policy options for UK nature conservation. Journal of Applied Ecology 47(5): 1365-2664. https://doi.org/10.1111/j.1365-2664.2010.01863.x

Troupin D, Carmel Y (2014) Can agro-ecosystems efficiently complement protected area networks? Biological Conservation 169: 158-166. https://doi.org/10.1016/j.biocon.2013.11.009

Tscharntke T, Klein AM, Kruess A, Steffan-Dewenter I, Thies C (2005) Landscape perspectives on agricultura-1 intensification and biodiversity - ecosystem service management. Ecology Letters 8(8): 857-874. https://doi.org/10.1111/j.1461-0248.2005.00782.x

Tsintides T, Christodoulou CS, Delipetrou P, Georghiou K (Eds) (2007) The Red Data Book of the Flora of Cyprus. Cyprus Forestry Association, Nicosia, 466 pp.

Vos C, Berry P, Opdam P, Baveco H, Nijhof B, O’Hanley J, Bell C, Kuipers H (2008) Adapting landscapes to climate change: Examples of climate-proof ecosystem networks and priority adaptation zones. Journal of Applied Ecology 45(6): 1722-173. https://doi.org/10.1111/ j.1365-2664.2008.01569.x

Vogiatzakis IN, Manolaki P (2017) Investigating the diversity and variability of Eastern Mediterranean landscapes. Land (Basel) 6(4): 71. https://doi.org/10.3390/land6040071

Zhang W, Ricketts TH, Kremen C, Carney K, Swinton SM (2007) Ecosystem services and disservices to agriculture. Ecological Economics 64(2): 253-260. https://doi.org/10.1016/j. ecolecon.2007.02.024 